\title{
Mário Sayeg: médico, professor e ativista
}

Conheço Mário Sayeg há mais de 25 anos. Quando ingressei na Fundação Oswaldo Cruz (FIOCRUZ), em 1976, ele era o Professor Sayeg e me ensinou muito com a sua visão de planejamento de saúde. Logo depois, o professor assumiu a posição de Diretor de Planejamento da FIOCRUZ. Neste cargo, criou, com Guilardo Martins Alves, então Presidente, uma estrutura consistente para a instituição.

Com o passar dos anos, o "professor" antecedendo seu nome - que eu utilizava no início - sumiu, por insistência dele ("não me deixe mais velho"; "você já tem senhoridade para me chamar de você"; etc.). Cresciam, a cada dia, uma imensa admiração e respeito por várias coisas que ele fez.

Primeiro, pela forma enérgica, embora carregada de paciência e tolerância - duas de suas maiores virtudes - com que ele se aventurou, há mais de dez anos, quando não era ainda moda, no campo da Gerontologia, que se afigurava como novidade. Não da visão clínica, focada nos indivíduos idosos, mas enquanto questão coletiva, de saúde pública.

Foi um pioneiro aqui no Brasil nesta área e, como tal, desbravou caminhos e enfrentou posturas de descrédito por parte daqueles que não entendiam a magnitude e a transcendência do que ele apregoava como "uma prioridade de hoje e do futuro": a crescente presença dos idosos na sociedade, caracterizando-se, por isso mesmo, como uma questão importantíssima para a saúde pública contemporânea.

Com esta visão quase premonitória, criou o Núcleo de Saúde do Idoso do Departamento de Administração e Planejamento da Escola Nacional de Saúde Pública (ENSP), aqui na FIOCRUZ, enquanto Piquet Carneiro desbravava o mesmo terreno na Universidade do Estado do Rio de Janeiro. Naquelas alturas, penso que o ajudei muito, dando todo o apoio possível - diante da incompreensão de muitos - às invencionices que ele me trazia, no campo do ensino e da pesquisa na terceira idade.

Agregou gente de diferentes profissões e disciplinas em torno dele no Núcleo então criado e formou centenas de profissionais, em um dos primeiros programas acadêmicos do país que ligava a saúde pública com as questões dos idosos. Em decorrência disto, estruturou, com liderança e capacidade de agregação, a Sociedade de Geriatria e Gerontologia, seção Rio de Janeiro, hoje uma sociedade respeitada nacionalmente.

Com seu jeito sorridente, simpático e cativante, foi superando as barreiras e driblando as dificuldades, como ocorre com todos os pioneiros.

Ao final, este número especial dos nossos Cadernos de Saúde Pública o homenageia em alto estilo: reunindo os melhores pensadores e investigadores da área da saúde do idoso, muito discípulos seus, para celebrar aquilo que ele tem de melhor e que eu nunca deveria ter retirado do vocativo com que o chamava: Professor Mário Sayeg, dos bons, e de tanta gente pelo Brasil afora!

Junto com Dalva, que também quero lembrar neste pequeno e emocionado texto, forma uma dupla formidável, como se olhassem ambos, com benevolência, compromisso e ternura, o todo da nossa população: ela, nossas crianças e adolescentes; ele, nossos velhinhos, que todos seremos um dia.

Salve, Mário Sayeg, mestre e sábio, que ainda hoje enriquece com suas idéias e seu jeito agradável, suave e elegante os nossos dias aqui na Fiocruz!

Paulo M. Buss

Presidência, Fundação Oswaldo Cruz, Rio de Janeiro, Brasil. 


\section{Mário Sayeg: physician, professor, and activist}

I have known Mário Sayeg for more than 25 years. When I joined the Oswaldo Cruz Foundation (FIOCRUZ) in 1976, he was still "Professor Sayeg" to me, and he taught me a great deal with his extraordinary vision of health planning. Soon after I joined the Foundation Professor Sayeg took over as Director of Planning at FIOCRUZ. In this position, and together with then-President Guilardo Martins Alves, he established a solid insfrastructure for the institution.

As the years went by, the "Professor" before his name - which I used in the beginning - gradually disappeared, at his insistence ("Don't make me sound older", "You have enough seniority to treat me on a first-name basis", etc.). Day by day, my admiration and respect grew for Mário Sayeg and his numerous accomplishments.

First, because of the energetic approach (albeit tempered by patience and tolerance - two of his greatest virtues) with which he launched into the field of Gerontology over ten years ago, when it was still not the fashion; rather Gerontology was emerging as a new field (not from the clinical perspective focused on individual seniors, but as a collective issue for public health).

Mário Sayeg was a pioneer in Brazil in this field, and as such he blazed trails and withstood the skepticism of those who failed to understand the magnitude and transcendence of what he preached as "a priority for today and the future": the growing presence of senior citizens in society, and for this very reason a key issue for contemporary public health.

With this almost premonitory vision, he created the Center for Senior Citizens' Health in the Department of Administration and Planning at the National School of Public Health (ENSP), here at FIOCRUZ, while Piquet Carneiro was opening the same terrain at the Rio de Janeiro State University. I had the privilege of assisting Mário Sayeg in this process, providing as much support as possible in the face of skepticism on the part of many towards what they considered quirky proposals in the field of teaching and research related to the elderly.

Mário Sayeg drew people from different professions and fields to join him at the recently created Center and trained hundreds of professionals in one of Brazil's first academic programs linking public health to senior citizens' issues. As a result, he took the leading role in organizing the first Rio de Janeiro chapter of the Society of Geriatrics and Gerontology, now a nationally renowned society.

With his smiling, friendly, and captivating demeanor, he leapt the hurdles and skirted the difficulties one by one, as occurs with all pioneers.

Finally, this special issue of Cadernos de Saúde Pública/Reports in Public Health devoted to the elderly pays tribute to Mário Sayeg in high style: convening the best thinkers and researchers in the field of senior citizens' health, many of whom are his disciples, to celebrate his finest trait, which I should never have removed from the vocative by which I called him: Professor Mário Sayeg, professor par excellence, and for so many people from all over Brazil!

Together with Dalva (to whom I also wish to pay tribute in this brief but heartfelt note), Mário forms a formidable couple, watching over the entire Brazilian population with dedication, commitment, and kindness: she, with our children and adolescents; he, with our old-timers, which we shall all become some day.

From all of us here at FIOCRUZ, long life and health to you, Mário Sayeg, master and visionary, enriching us to this day with your ideas, your good nature, and your refined expertise!

Paulo M. Buss

Presidência, Fundação Oswaldo Cruz, Rio de Janeiro, Brasil. 